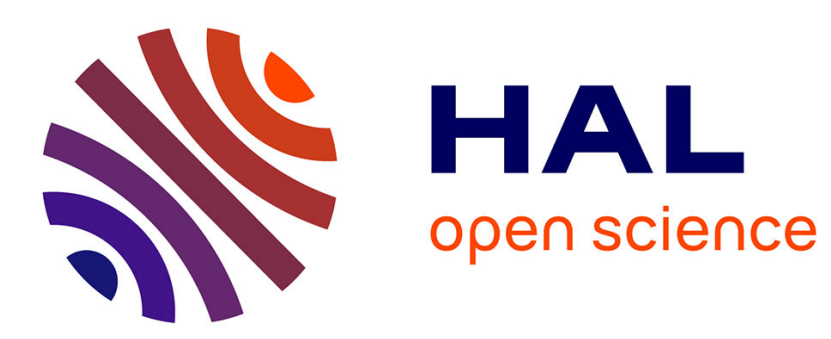

\title{
Structural Effects of Cu,Zn Substitution in the Malachite-Rosasite System
}

\author{
Malte Behrens, Frank Girgsdies
}

\section{To cite this version:}

Malte Behrens, Frank Girgsdies. Structural Effects of $\mathrm{Cu}, \mathrm{Zn}$ Substitution in the Malachite-Rosasite System. Journal of Inorganic and General Chemistry / Zeitschrift für anorganische und allgemeine Chemie, 2010, 10.1002/zaac.201000028 . hal-00552444

\section{HAL Id: hal-00552444 https://hal.science/hal-00552444}

Submitted on 6 Jan 2011

HAL is a multi-disciplinary open access archive for the deposit and dissemination of scientific research documents, whether they are published or not. The documents may come from teaching and research institutions in France or abroad, or from public or private research centers.
L'archive ouverte pluridisciplinaire HAL, est destinée au dépôt et à la diffusion de documents scientifiques de niveau recherche, publiés ou non, émanant des établissements d'enseignement et de recherche français ou étrangers, des laboratoires publics ou privés. 


\section{Structural Effects of $\mathrm{Cu}, \mathrm{Zn}$ Substitution in the Malachite- Rosasite System}

\begin{tabular}{|c|c|}
\hline Journal: & Zeitschrift für Anorganische und Allgemeine Chemie \\
\hline Manuscript ID: & zaac. 201000028.R1 \\
\hline Wiley - Manuscript type: & Article \\
\hline $\begin{array}{l}\text { Date Submitted by the } \\
\text { Author: }\end{array}$ & 02-Mar-2010 \\
\hline Complete List of Authors: & $\begin{array}{l}\text { Behrens, Malte; Fritz-Haber-Institute, Inorganic Chemistry } \\
\text { Girgsdies, Frank; Fritz-Haber-Institute, Inorganic Chemistry }\end{array}$ \\
\hline Keywords: & $\mathrm{Cu} / \mathrm{ZnO}$ catalyst, Jahn-Teller distortions, Malachite, Rosasite \\
\hline
\end{tabular}

\section{(5) ScholaroNE \\ Manuscript Central}


a) Fritz-Haber-Institut der Max-Planck-Gesellschaft

Abteilung Anorganische Chemie

Berlin, Germany

Malte Behrens $^{\mathrm{a}, *}$ and Frank Girgsdies ${ }^{\mathrm{a}}$

Dedicated to Professor Rüdiger Kniep on the Occasion of his $65^{\text {th }}$ birthday

* Corresponding author: Dr. Malte Behrens

Fritz-Haber-Institut der Max-Planck-Gesellschaft

Abteilung Anorganische Chemie

Faradayweg 4-6

14195 Berlin

Germany

Email:behrens@fhi-berlin.mpg.de

Tel.: +49 30 8413-4408

Fax: +49 30 8413-4405 


\begin{abstract}
Synthetic zincian malachite samples $\left(\mathrm{Cu}_{1-\mathrm{x}} \mathrm{Zn}_{\mathrm{x}}\right)_{2}(\mathrm{OH})_{2} \mathrm{CO}_{3}$ with $x=0,0.1,0.2$ and 0.3 were characterized by powder X-ray diffraction and optical spectroscopy. The XRD patterns of the samples up to $\mathrm{x}=0.2$ indicate single phase materials with an approximately linear dependence of the refined lattice parameters on the $\mathrm{Zn}$ content. In contrast, the sample with a nominal $\mathrm{Zn}$ content $x=0.3$ shows the formation of a small amount of aurichalcite $(\mathrm{Zn}, \mathrm{Cu})_{5}(\mathrm{OH})_{6}\left(\mathrm{CO}_{3}\right)_{2}$ as an additional phase. Based on the lattice parameter variations, the $\mathrm{Zn}$ content of the zincian malachite component in this sample is estimated to be $\mathrm{x} \approx 0.27$, which seems to represent the maximum possible substitution in zincian malachite under the synthesis conditions applied. The results are discussed in relation to preparation of $\mathrm{Cu} / \mathrm{ZnO}$ catalysts and the crystal structures of the minerals malachite and rosasite. One striking difference between these two structurally closely related phases is the orientation of the Jahn-Teller elongated axes of the $\mathrm{CuO}_{6}$ octahedra in the unit cell, which seems to be correlated with the placement of the monoclinic $\beta$ angle. The structural and chemical relationship between these crystallographically distinct phases is discussed using a hypothetical intermediate $\mathrm{Zn}_{2}(\mathrm{OH})_{2} \mathrm{CO}_{3}$ phase of higher orthorhombic symmetry. In addition to the crystallographic analysis, optical spectroscopy proves to be a useful tool for estimation of the $\mathrm{Cu}: \mathrm{Zn}$ ratio in $\left(\mathrm{Cu}_{1-\mathrm{x}} \mathrm{Zn}_{\mathrm{x}}\right)_{2}(\mathrm{OH})_{2} \mathrm{CO}_{3}$ samples.
\end{abstract}

\title{
Keywords
}

Malachite, Rosasite, Jahn-Teller distortions, $\mathrm{Cu} / \mathrm{ZnO}$ catalyst

\section{Introduction}

Rosasite is a mineral of the chemical composition $\left(\mathrm{Cu}_{1-\mathrm{x}} \mathrm{Zn}_{\mathrm{x}}\right)_{2}(\mathrm{OH})_{2} \mathrm{CO}_{3}$ with approximately $0.3<\mathrm{x}<0.5$. The related pure $\mathrm{Cu}$ mineral, $\mathrm{Cu}_{2}(\mathrm{OH})_{2} \mathrm{CO}_{3}$, is malachite whose monoclinic crystal structure is reported in the literature [1.]. While synthetic malachite can be easily prepared by precipitation, synthetic rosasite samples, i.e. single phase compounds with $\mathrm{x}>0.3$, are much harder to obtain, because usually aurichalcite, $\left(\mathrm{Cu}_{1-\mathrm{x}} \mathrm{Zn}_{\mathrm{x}}\right)_{5}(\mathrm{OH})_{6}\left(\mathrm{CO}_{3}\right)_{2}$ with $\mathrm{x}>0.5$, is formed if zinc-rich solutions are used for coprecipitation [2]. The cell parameters and space group of rosasite have been reported in 
[3] and atomic coordinates were recently revealed on the basis of powder diffraction studies [4]. Both malachite and rosasite are monoclinc, space group $P 2_{1} / a$ (No. 14), crystallize in different crystal structures and are, thus, not isomorphous despite their similar compositions. However, the close relation of the two phases is apparent from the similar powder diffraction patterns (Fig. 1) and was recently discussed by Perchiazzi $[4,5]$. It is interesting to note that rosasite analogous minerals were found also with $\mathrm{Mg}$, $\mathrm{Ni}$ or Co instead of $\mathrm{Zn}$ together forming the rosasite group of minerals.

These mixed basic transition metal carbonates have not only attracted the attention of mineralogists, but also of solid state chemists active in the field of heterogeneous catalysis, because $\left(\mathrm{Cu}_{1-\mathrm{x}} \mathrm{Zn}_{\mathrm{x}}\right)(\mathrm{OH})_{2} \mathrm{CO}_{3}$ is the relevant precursor compound for the preparation of nanostructured $\mathrm{Cu} / \mathrm{ZnO}$ catalysts [6-.9]. Such catalysts are employed in industrial synthesis of methanol from syngas, one of the top ten chemical processes worldwide. A highly substituted synthetic rosasite-like precursor would be desirable for catalyst preparation, because the resulting $\mathrm{Cu} / \mathrm{ZnO}$ material after calcination and reduction is expected to exhibit a higher dispersion of the catalytically active $\mathrm{Cu}$ phase. This is because the stabilizing function of the $\mathrm{ZnO}$ phase in the composite catalyst is more efficient, if large amounts of $\mathrm{Zn}$ were homogenously distributed in the cation lattice of the precursor (Fig. 2) [6]. However, preparation of $\left(\mathrm{Cu}_{1-\mathrm{x}} \mathrm{Zn}_{\mathrm{x}}\right)(\mathrm{OH})_{2} \mathrm{CO}_{3}$ with substitution levels near $x=0.5$, i.e. as high as in natural rosasite, remains a challenge and values around $\mathrm{x}=0.3$ cannot be exceeded for state-of-the-art catalysts synthesized from malachite/rosasite-like precursors. Zn-richer aurichalcite precursors were shown to lead to inferior catalysts because aurichalcite is usually obtained in form of large platelets exhibiting an unfavorable meso-structure compared to the needle-like zincian malachite. We have started to investigate the structural properties of mixed basic $\mathrm{Cu}, \mathrm{Zn}$ carbonates from the perspective of $\mathrm{Cu} / \mathrm{ZnO}$ catalyst preparation and first results have been reported recently $[2,6]$. Here, we report on the effects of $\mathrm{Cu}$ by $\mathrm{Zn}$ substitution on the crystal structure and optical absorption properties of malachite and discuss the relationship between synthetic $\left(\mathrm{Cu}_{1-\mathrm{x}} \mathrm{Zn}_{\mathrm{x}}\right)(\mathrm{OH})_{2} \mathrm{CO}_{3}$ and to natural samples of malachite and rosasite.

\section{Results and Discussion}


A comparison of the crystal structures of natural malachite [1] and rosasite [4] based on literature data, is shown in Figure 3. The main building blocks are $(\mathrm{Cu}, \mathrm{Zn}) \mathrm{O}_{6}$ octahedra and two distinct metal sites are present in both structures (Tab. 1). As pointed out by Perchiazzi [4], the view along the $c$-axis (Fig. 3, top row) shows equal connectivity of the octahedral units in both minerals in form of "double ribbons" of two edge-sharing octahedra running along [001]. The major structural difference of the two phases becomes apparent if the view is slightly tilted towards the (110) plane (Fig. 3, bottom row), showing that the monoclinic angle is placed between the short and the medium axes in malachite but between the short and the long axes in rosasite. Thus, one might get the idea that both in malachite and rosasite the monoclinic angle $\beta$ is shifted towards $90^{\circ}$ as the $\mathrm{Cu}: \mathrm{Zn}$ ratio changes and that a hypothetical orthorhombic parent structure exists for both minerals, possibly at an intermediate value of $x$.

The effects of substitution of $\mathrm{Cu}$ by $\mathrm{Zn}$ on the crystal structure of synthetic malachite, leading to zincian malachite, $\left(\mathrm{Cu}_{1-\mathrm{x}} \mathrm{Zn}_{\mathrm{x}}\right)(\mathrm{OH})_{2} \mathrm{CO}_{3}$, were first investigated in detail by Porta et al. in 1988 [10,11]. The authors report a contraction of the unit cell and a systematic shift for the $h 0 l$ and $h k l$ reflections. We have recently reported a characteristic and very pronounced shift of the (20 -1) and (21 -1) reflections to higher angles in the $\mathrm{XRD}$ patterns as $\mathrm{Cu}$ is gradually substituted by $\mathrm{Zn}$ [2]. The unusual effect on these characteristic XRD peaks was explained as a ligand field effect. In brief, the Jahn-Teller elongated axes of the $\mathrm{CuO}_{6}$ octahedra in malachite exhibit an orientation nearly perpendicular to either the $(20-1)$ or $(21-1)$ lattice planes (Fig. 4). The unit cell is strongly contracted in the directions perpendicular to these planes as the Jahn-Teller ions $\mathrm{Cu}^{2+}$ are substituted with $\mathrm{Zn}^{2+}$ forming more regular octahedra. Thus, the $d$-spacing of these characteristic reflections can be used as a sensitive indicator for the degree of $\mathrm{Zn}$ incorporation in the malachite structure.

It remains, however, puzzling that certain reflections move strongly, while others remain more or less fixed (Fig. 5) despite their interrelation via the cell parameters. In particular, the intensive $\mathrm{XRD}$ peaks below $30^{\circ} 2 \theta$, which are often used as fingerprint reflections for precursor phase identification in catalysis research, do hardly give information on the $\mathrm{Cu}: \mathrm{Zn}$ ratio. This could be generally expected from the similar ionic radii of $\mathrm{Cu}^{2+}$ and $\mathrm{Zn}^{2+}$, but at the same time the $(20-1)$ and $(21-1)$ peaks in the $2 \theta$-range $31-33^{\circ}$ indicate 
pronounced changes of the cell parameters. In addition, the low-angle reflections are not suitable to unambiguously discriminate the malachite and rosasite structures in the mineral phases (Fig. 1). This stimulated us to perform full pattern refinements of synthetic zincian malachite samples with nominal molar $\mathrm{Cu}: \mathrm{Zn}$ ratios of 100:0, 90:10, 80:20 and 70:30 using the mineral malachite as structural model. The samples were synthesized according to established catalyst precursor preparation [12] by coprecipitation and subsequent ageing of the precipitate in the mother liquor, during which crystallization occurs. The Rietveld-fits are graphically shown in Figure 5 and selected results are listed in Table 2. It is noted that the crystallinity of the materials decreased with increasing $\mathrm{Zn}$ content. Furthermore, the 70:30 Zn sample contained aurichalcite as an additional phase. For the single phase materials (samples up to $\mathrm{x}=0.2$ ), a full Rietveld refinement of the atomic coordinates was possible and included in the fitting procedure. In contrast, the poor crystallinity and presence of the aurichalcite by-phase did not allow a reliable refinement of atomic positions for the 70:30 sample. Thus, fixed atomic coordinates as obtained from the fit of the 80:20 sample were used in this case.

The unit cell volume and especially the $b$-axis of the synthetic malachite sample (Tab. 2) were found to be slightly decreased in comparison to the natural samples (Tab. 1). The $\mathrm{Cu}-\mathrm{Zn}$ substitution in malachite leads to a Vegard-type linear trend for all lattice parameters of $\left(\mathrm{Cu}_{1-\mathrm{x}} \mathrm{Zn}_{\mathrm{x}}\right)_{2}(\mathrm{OH})_{2} \mathrm{CO}_{3}$ in the range $0<\mathrm{x}<0.2$ (Fig. 6). The $a$ - and $c$-axes, the monoclinic $\beta$ angle as well as the unit cell volume (Tab. 2) decrease with increasing $\mathrm{Zn}$ content, whereas the $b$-axis increase. These observations are in line with the results reported by Porta et al. [11,12], who obtained phase pure zincian malachite samples for $x$ $\leq 0.15$. The lattice parameters of their samples are in reasonable agreement with our results and are also shown in Figure 6. It was discussed in [2] that the average contraction of the Jahn-Teller elongated octahedra might be responsible for the cell volume shrinking. The slightly larger ionic radius of $\mathrm{Zn}^{2+}$ and the elongation of the equatorial M$\mathrm{O}$ bonds are reflected in the increasing $b$-axis, but obviously do not compensate for the shrinking effect. Porta et al. suggested that covalent shortening is responsible for the unit cell volume contraction as the ionic $\mathrm{Cu}-\mathrm{O}$ bond is substituted by more covalent $\mathrm{Zn}-\mathrm{O}$.

Porta et al. also discussed the non-systematic shift of certain groups of reflections [11]. The simultaneous anisotropic change of the lattice parameters causes only minor changes 
in the XRD patterns, reflected strongly only in the positions of the (20 -1) and (21 -1) reflections as discussed above. For instance, the shift of the well-resolved (200) reflection near $19^{\circ} 2 \theta$ is only hardly detected in the XRD patterns of the poorly crystalline catalyst precursors (Fig 5), although the $a$-axis is significantly contracted (Fig. 6a). This is because low-angle reflections generally shift less on the angular scale, but also, because the effect of the contracted $a$-axis $(-1.3 \%$ at $x \approx 0.3)$ is to some extent compensated by the simultaneous decrease of $\beta$ leading to smaller changes in the $d$-spacing of the $(h 00)$ planes of only $-0.7 \%$. These peculiarities are summarized in Figure 7 for the six most intensive reflections of zincian malachite showing again the special sensitivity of the (20 -1) and (21 -1) peaks for the $\mathrm{Cu}: \mathrm{Zn}$ ratio and the much smaller effect of the structural changes on the other peaks, especially on the angular scale of a conventional $\mathrm{Cu} \mathrm{K}_{\alpha}$ pattern (Fig. 7b).

The $\mathrm{Zn}$ content of the malachite-like phase fraction in the 70:30 sample was estimated on basis of the linear trends shown in Figure 6. Linear regressions were performed using the first three data points (single phase samples) for all four lattice parameters. The best overall agreement for the lattice parameters of the zincian malachite phase in the fourth sample is obtained when placing it at $x=0.27$ (Fig. 6). This in the range $0.23<x<0.33$ suggested by Porta et al. on basis of the cell volume contraction [10,11] and in excellent agreement with the limit of $x=0.28$ determined from the shift of the (20 -1) reflection by single peak fitting in a previous study [2]. It is noted, though, that the values scatter between 0.25 ( $b$-axis) to 0.28 (monoclinic $\beta$ angle), if the $\mathrm{Zn}$ content was estimated for each cell parameter separately.

As laboratory XRD provides no direct access to the distribution of $\mathrm{Cu}$ and $\mathrm{Zn}$ on the two available metal sites in the malachite structure, the site preference has to be deduced indirectly from the average distortion of the $\mathrm{MO}_{6}$ coordination polyhedra in the structure. Thus, distortion parameters $\Delta$ were calculated from the M-O distances $\mathrm{d}$ of the M1 and M2 sites according to $\Delta=(1 / 6) \sum_{n=1,6}\left\{\left(d_{n}-\langle d\rangle\right) /\langle\mathrm{d}\rangle\right\}^{2}$, with $\langle\mathrm{d}\rangle$ being the average M-O distance and $d_{n}$ the individual distances (Fig. 6e, Tab. 1,2) [5,13]. It can be expected that starting from the strongly Jahn-Teller distorted malachite structure, the parameter $\Delta$ should decrease for a specific site upon successive substitution of $\mathrm{Cu}$ with $\mathrm{Zn}$. It can be seen in Figure 6e, that this is the case for the M2 site, while M1 does not show a clear 
trend. Such a $\mathrm{Zn}$ ordering on the M2 site is also expected from ligand field considerations, because $(\mathrm{M} 2) \mathrm{O}_{6}$ is the initially less distorted polyhedron in pure malachite (Tab. 1) and thus more suited for the coordination requirements of $\mathrm{Zn}^{2+}$. The difference between the M1 and M2 sites is much more pronounced in natural malachite compared to our synthetic material, i.e. the M1 site is more distorted and the M2 more regular (Fig. 6e). This is possibly because a naturally formed mineral should be closer to the thermodynamically favorable site distribution than a synthetic sample, which would be influenced more strongly by randomizing kinetic factors. Consequently, site preference upon $\mathrm{Cu}-\mathrm{Zn}$ substitution can be expected to be more pronounced in minerals than in synthetic samples. The M1:M2 ratio in the malachite unit cell is $1: 1$ and extrapolation of $\Delta$ indicates that a hypothetical undistorted $(\mathrm{M} 2) \mathrm{O}_{6}$ is present for $\mathrm{Zn}$ contents around $\mathrm{x}=0.5$, suggesting that $\mathrm{M} 2$ is almost exclusively preferred by $\mathrm{Zn}$ also for high substitution levels. This is also in good agreement with the distortion parameters of (M2) $\mathrm{O}_{6}$ calculated for natural rosasite (Tab. 1, Fig. 6e) and the site occupancy reported by Perchiazzi $[4,5]$. However, it should be mentioned in this context that the two M2-O bonds in rosasite, which are significantly longer than the remaining four (Tab. 1), are cis to each other, and the resulting distortion $\Delta$ is not compatible with the trans geometry expected for a Jahn-Teller distorted site.

Coming back to the structural relation of (zincian) malachite and rosasite, indeed an evolution towards $90^{\circ}$ is observed for the monoclinic angle $\beta$ as $\mathrm{Zn}$ is incorporated into malachite. However, it is clearly seen in Figure $6 \mathrm{~d}$ that $90^{\circ}$ is not reached at intermediate values of $\mathrm{x}$ and that no such orthorhombic parent structure exists in between the regimes of zincian malachite (up to $\mathrm{x} \approx 0.3$ ) and rosasite $(0.3<\mathrm{x}<0.5)$. However, it is interesting to note that the monoclinic angle of malachite indeed becomes $90^{\circ}$ as it is extrapolated to $\mathrm{x}=1$ (Fig. 6d), suggesting a hypothetical orthorhombic Zn-only phase $\mathrm{Zn}_{2}(\mathrm{OH})_{2} \mathrm{CO}_{3}$, which to our knowledge has not been reported so far. Following the highly idealized trends shown in Figure 6e as dashed lines, such pure $\mathrm{Zn}_{2}(\mathrm{OH})_{2} \mathrm{CO}_{3}$ phase can be assumed to consist of relatively regular octahedral building units due to the absence of $\mathrm{Cu}^{2+}$. Starting from malachite, Zn substitution first occurs preferably on the M2 site until $x=$ 0.5 . Beyond this value, the M1 site is necessarily filled with $\mathrm{Zn}^{2+}$, leading to successive decrease of the average distortions of the respective octahedra and, in the end, apparently 
also of the monoclinic distortion of the unit cell. These considerations are highly idealized, because other contributions than Jahn-Teller distortions that may contribute to the monoclinic distortion of the unit cell are neglected. It is noted in this context that the structures of the minerals pokrovskite [5] and chukanovite [14], $\mathrm{M}_{2}(\mathrm{OH})_{2} \mathrm{CO}_{3}$ with $\mathrm{M}=$ $\mathrm{Mg}^{2+}$ and $\mathrm{Fe}^{2+}$, respectively, can be refined in the monoclinic rosasite structure type despite the absence of Jahn-Teller ions, suggesting an intrinsic monoclinic distortion of these minerals. Interestingly, a sub-stochiometric occupation of the cation sites was reported for the former and could not be excluded for the latter mineral.

However, the simplified picture of hypothetical, undistorted, orthorhombic $\mathrm{Zn}_{2}(\mathrm{OH})_{2} \mathrm{CO}_{3}$ allows an "inverse" gedankenexperiment, in which malachite and rosasite are derived from such common $\mathrm{Zn}_{2}(\mathrm{OH})_{2} \mathrm{CO}_{3}$ phase as starting material. Assuming $\mathrm{Cu}-\mathrm{Zn}$ ordering for both phases, the M1 site would be gradually filled with $\mathrm{Cu}^{2+}$ now introducing JahnTeller elongation of given axial M1-O bonds in the initially almost undistorted octahedra. In this situation, different possibilities for the orientation of these elongated axes in the unit cell exist, as there is the choice between the three orthogonal four-fold rotation axes of the $\mathrm{M} 1 \mathrm{O}_{6}$ octahedra. This leads to the principal difference of the malachite and the rosasite structure as can be seen in Figure 8 showing both crystal structures along their crystallographic axes. It is noted that because of the different orientation of the monoclinic angles, and according to crystallographic convention, requireing the $b$-axis to be the monoclinic axis, the $a$-axis of malachite corresponds to the $b$-axis of rosasite, and vice versa. Thus, the [010] view of malachite is analogous to the [100] view of rosasite (Fig. 8, top row), while the structural situation in malachite viewed along [100] is represented in the [010] view of rosasite (Fig. 8, center row).

The Jahn-Teller elongated bonds of the $\mathrm{CuO}_{6}$ polyhedra of those metal sites which are mainly occupied by $\mathrm{Cu}$ (M1 and M2 in malachite and M1 in rosasite) are emphasized in black in Figure 8. It can be seen that, when viewed along the long axes (top row), their projections are aligned almost in parallel in malachite, while they exhibit a nearly perpendicular zig-zag arrangement in rosasite. Conversely, when viewed along the medium axes (center row), they are almost parallel in rosasite and a little staggered in malachite, still being far away from a rectangular arrangement. At low $\mathrm{Cu}: \mathrm{Zn}$ ratios, i.e. if the Jahn-Teller distorted units are diluted, the perpendicular zig-zig arrangement 
(rosasite structure) seems to be favorable, while at high $\mathrm{Cu}: \mathrm{Zn}$ rations, i.e. if the JahnTeller distortions are concentrated, a more parallel orientation seems to be more stable resulting in the malachite structure. Thus, the hypothetical $\mathrm{Zn}_{2}(\mathrm{OH})_{2} \mathrm{CO}_{3}$ phase helps to understand the existence of different non-isomorphous structures for malachite and rosasite despite their similar composition and crystallization in the same class of space groups. In this context, the projections in Figure 8 are very suggestive, as it appears that the different monoclinic distortion in both minerals can be explained by the direction of parallel orientation of the projected Jahn-Teller elongations opening the respective angle to $>90^{\circ}$ (top row, left and center row right). Finally, the differences of the malachite and rosasite structures can also be seen in the view along the short axis if the elongated bonds are considered (bottom row). In rosasite, the Jahn-Teller elongated bonds of (M1) $\mathrm{O}_{6}$ point to the same carbonate ligand, while for malachite there is only one black bond per carbonate anion.

While the XRD pattern of our mineral malachite sample could be fitted easily (Tab. 1, Fig. 1), we encountered problems in the attempt to refine the rosasite structure. Due to anisotroptic peak broadening, no satisfying agreement of calculated and experimental pattern could be obtained. Furthermore, preliminary results using only the rosasite structure suggested presence of an additional phase since it could not account for two weak reflections at 31.9 and $32.9^{\circ} 2 \theta$, which have been already mentioned in [2] and are marked in Figure 1b. The fit became significantly better, though still not good enough for a reliable refinement of the atomic positions, when an additional (zincian) malachite phase was introduced as has been suggested in [2]. In Figure 1b only the resulting peak positions of such two phase fit are shown and the corresponding cell parameters are given in Table 1, showing that it is possible to have a mixture of the zincian malachite and rosasite phases, in which most of the well-resolved and intense XRD reflections overlap resulting in complex peak profiles. The (20 -1) and (21 -1) peaks of malachite are the striking exception among the intense reflections and the most obvious indication of the malachite-like phase fraction. It either is present as a separated impurity phase or as domains in the rosasite crystals resulting from fluctuations of the $\mathrm{Zn}$ content. On the basis of the linear trends shown in Figure 6, the $\mathrm{Zn}$ content $x$ of this fraction of the mineral sample can be estimated to ca. 0.18 falling clearly below the average value of 0.38 
determined by EDX. It is noted, though, that the scattering among the individual lattice constant was in the range $0.13<x<0.25$.

As a complementary technique, optical absorption spectroscopy was applied for natural as well as synthetic samples with nominal Zn contents of $x=0,0.1$ and 0.3 . The spectra are shown in Figure 9. As expected, those of natural and synthetic malachite are similar. For malachite two major contributions are observed, an intensive band centered around $810 \mathrm{~nm}$ and a shoulder at lower energies near $1150 \mathrm{~nm}$. These are typical features of tetragonally distorted octahedral $\mathrm{CuO}_{6}$ chromophors [15-17]. Significant changes can be observed as the $\mathrm{Zn}$ content of the samples is increased. The subtle change of the color of the samples from green to bluish green is caused by a slight blue-shift of the former band into the vis-range of the spectrum and development of a shoulder at high energy seen most clearly in the spectrum of rosasite (indicated by an arrow in Fig. 9). However, the changes are much more pronounced at lower energy in the NIR. This spectral range was reported to be suitable for discrimination of rosasite group minerals [18]. The band at $1150 \mathrm{~nm}$ was assigned to the ${ }^{2} \mathrm{~B}_{1 \mathrm{~g}} \rightarrow{ }^{2} \mathrm{~A}_{1 \mathrm{~g}}$ transition of $\mathrm{Cu}^{2+}[18]$ and its relative intensity decreases as copper is substituted by optically silent $\mathrm{Zn}^{2+}$. The band is also shifted to lower energies, which may be associated with the geometrical effect of the $\mathrm{Zn}^{2+}$ ions on the $\mathrm{MO}_{6}$ polyhedra as shown above in Figure $6 \mathrm{e}$ affecting also the $\mathrm{CuO}_{6}$ chromophors. The rough correlation of the position of this band with the Zn content (Fig. 10) renders optical spectroscopy in the range $>1000 \mathrm{~nm}$ an alternative tool for convenient estimation of the $\mathrm{Cu}: \mathrm{Zn}$ ratio in zincian malachite, which is not affected by the crystallographic differences of malachite and rosasite.

In summary, these results suggest a relative phase stability of mixed $\mathrm{Cu}, \mathrm{Zn}$ basic carbonates as shown in the simplified free energy diagram in Figure 11. At $x=0$, malachite is the most stable phase and synthetically easily accessible. As $x$ increases low amount of $\mathrm{Cu}$ in malachite can be substituted by $\mathrm{Zn}$ leading to zincian malachite (black curve in Fig. 11). At a critical composition, no more $\mathrm{Zn}$ can be incorporated into zincian malachite and formation of a phase mixture of zincian malachite and aurichalcite is energetically favorable. The reason is most probably the increasing concentration of regular $\mathrm{MO}_{6}$ octahedra, which destabilizes the aligned arrangement of the Jahn-Teller distortions present in malachite. Aurichalcite (light grey curve) exhibits a higher 
variability of building units [19], e.g. also tetrahedrally coordinated and almost undistorted octahedral sites are available, which can accommodate $\mathrm{Zn}$ ions [20]. Under the synthesis conditions applied for this study the critical composition is at $x=$ 0.27 and the two-phase regime lasts until $x$ ca. 0.5 [21]. It is noted that these values strongly depend on the exact setting of the synthesis conditions like $\mathrm{pH}$, temperature and ageing time, but also on the general mode of co-precipitation. For instance, if the decreasing $\mathrm{pH}$ technique is used at otherwise the same conditions, the critical composition cannot exceed $x=0.11$ [2] and the two-phase regime ends at approximately $x=0.60$ [21]. Thus, the relative positions of the curves in Figure 11, which were chosen to qualitatively agree with thermodynamical data reported in literature [22], are a function of the synthesis parameters indicating that the applied method of preparation does not necessarily lead to equilibrium phases.

Rosasite seems to be metastable towards zincian malachite and/or aurichalcite at all compositions (dark grey curve) as it is not accessible by the co-precipitation and ageing procedure. According to the above considerations the curves of zincian malachite and rosasite should meet at $x=1$, the hypothetical common $\mathrm{Zn}_{2}(\mathrm{OH})_{2} \mathrm{CO}_{3}$ phase. Anyway, rosasite is accessible under naturally occuring mineralization conditions for compositions $0.3<x<0.5$.

Consequences of the situation depicted in Figure 11 for preparation and optimization of $\mathrm{Cu} / \mathrm{ZnO}$ catalysts relate to the observation that a coarse relationship between the $\mathrm{Zn}$ content $\mathrm{x}$ in $\left(\mathrm{Cu}_{1-\mathrm{x}} \mathrm{Zn}_{\mathrm{x}}\right)(\mathrm{OH})_{2} \mathrm{CO}_{3}$ and the catalytic activity of the resulting $\mathrm{Cu} / \mathrm{ZnO}$ catalyst exists [6]. Near the critical limit of 0.27 a maximum of gas accessible $\mathrm{Cu}$ surface areas, i.e. highest dispersion of $\mathrm{Cu}$, was observed due to an efficient nano-structuring of the precursor upon thermal treatment (Fig. 2). At $x>0.27$, aurichalcite is formed as a byphase and the decreasing catalytic activity is attributed to the unfavorable meso-structure of this precursor phase leading to undesired embedment of the active $\mathrm{Cu}$ particles. Thus, synthesis conditions have to be found, which either drive the critical composition of zincian malachite beyond $\mathrm{x}=0.27$ by lowering the black curve or make rosasite-like precursors accessible by lowering the dark grey curve.

\section{Conclusion}


The main conclusions of this work are: (i) Malachite and rosasite, $\left(\mathrm{Cu}_{1-\mathrm{x}} \mathrm{Zn}_{\mathrm{x}}\right)(\mathrm{OH})_{2} \mathrm{CO}_{3}$, which are not boundary cases of an isomorphous substitution series [4], can be envisaged as two alternative distortions of a hypothetical common orthorhombic parent structure as a function of $\mathrm{Cu}: \mathrm{Zn}$ ratio. Synthetic samples with a $\mathrm{Zn}$ content of up to $\mathrm{x}=0.27$ adopt the malachite-like structure, which exhibits a more coaxial arrangement of the Jahn-Teller distorted polyhedra and, thus, seems not to be able to incorporate larger amounts of preferably symmetrically coordinated $\mathrm{Zn}^{2+}$ ions. (iii) As expected, $\mathrm{Zn}$ preferably occupies the less distorted M2 site in synthetic zincian malachite and $\mathrm{Cu}-\mathrm{Zn}$ substitution leads to anisotropic, but linear Vegard-type changes of the malachite lattice constants, which due to a compensating effect are hardly reflected in the peak positions of most XRD reflections. (iii) In natural samples both phases may co-exist, possibly as domains with different $\mathrm{Zn}$ contents. This phase co-existence may be difficult to see by powder XRD, because the individual patterns are very similar and differ only in a few selected reflections. (iv) In addition to full pattern refinement or analysis of the d-spacing of the characteristic (20 -1) or (21 -1) peaks [2], optical spectroscopy can be applied to estimate the $\mathrm{Cu}: \mathrm{Zn}$ ratio in zincian malachite catalyst precursors.

\section{Experimental}

Mineral samples were obtained from the mineral collection of the Technical University Berlin. Elemental analysis by EDX revealed a $\mathrm{Zn}$ content $\mathrm{x}$ of 0.38 for the rosasite sample [2]. In case of malachite, EDX showed that in the mineral sample $7 \%$ of the cations were $\mathrm{Al}^{3+}$ or $\mathrm{Si}^{4+}$, which are probably present in an impurity phase not seen by XRD. However, another $2 \%$ are $\mathrm{Mg}^{2+}$, which could possibly reside on the $\mathrm{Cu}$ sites in the malachite structure. Further analyses of the minerals like TG and IR spectroscopic investigations can be found in [2]. The series of synthetic zincian malachite samples was prepared with varying molar $\mathrm{Cu} / \mathrm{Zn}$ ratios of 100:0, 90:10, 80:20 and 70:30 by constant$\mathrm{pH}$ co-precipitation and some results were presented in earlier contributions [2,6,21]. Co-precipitates were obtained by co-feeding mixed metal nitrate and soda solutions at $\mathrm{pH}$ 7 and $\mathrm{T}=65^{\circ} \mathrm{C}$. The initially amorphous precipitates (zincian georgeite [23]) were aged in the mother liquor for $2 \mathrm{~h}$. During ageing crystallization occurred and the solids were 
recovered by filtration, washing and drying. Further details on the preparation process can be found in ref. [21] and [6].

For the synthetic samples, the X-ray diffraction (XRD) measurements were performed on a STOE STADI P transmission diffractometer equipped with a primary focusing Ge monochromator $\left(\mathrm{Cu} \mathrm{K} \alpha_{1}\right.$ radiation) and a curved position sensitive detector (static mode, resolution $0.03^{\circ}$, accumulation time $1800 \mathrm{~s}$ ). The sample powders were filled into $0.3 \mathrm{~mm}$ diameter glass capillaries and mounted on a capillary sample holder which was rotated around the capillary axis during measurement. The mineral samples were measured on the same setup, except that a linear position sensitive detector was used (moving mode, step size $0.1^{\circ}$, counting time $10 \mathrm{~s} / \mathrm{step}$, resolution $0.01^{\circ}$, total accumulation time $634 \mathrm{~s}$ ) and the samples were mounted in the form of a clamped sandwich of small amounts of powder fixed with a small amount of grease between two layers of thin polyacetate film. Refinements were done in the $2 \theta$ range $5-90^{\circ}$ using the software package TOPAS [24]. Only $2 \theta$-sections of $10-50^{\circ}$ are shown in the figures for clarity. The background for the mineral samples was modelled using a third order Chebychev polynomial, while the synthetic samples required a second order Chebychev polynomial plus a very broad $\left(\mathrm{FWHM}>5^{\circ} 2 \theta\right)$ Gaussian peak around $25-30^{\circ} 2 \theta$ to account for the diffuse scattering caused by the glass capillary walls. Details of the refinements are given in Table 3.

Diffuse reflectance UV-vis-NIR spectroscopy was performed using a PerkinElmer Lambda 950 spectrometer equipped with a Harrick Praying Mantis DRP-P72 accessory and HVC-VUV reaction chamber. The spectra of selected samples were measured in the spectral range $250-2500 \mathrm{~nm}$ at room temperature in static air. For the background correction the Spectralon reflectance standard (Labsphere) was used. All spectroscopic measurements were carried out sequentially with a scan speed of $266 \mathrm{~nm} \min ^{-1}$, a nominal slit width of $2.5 \mathrm{~nm}$, a response time of $0.20 \mathrm{~s}$, and a step width of $1 \mathrm{~nm}$. The apparent absorption $\mathrm{K}(\lambda)$ as a function of the wavelength $\lambda$ was evaluated from the diffuse reflectance data using the Kubelka-Munk equation.

\section{Acknowledgements}

We thank Nicole Giliard and the Technical University Berlin for providing the mineral reference samples, Edith Kitzelmann for XRD measurements, Gisela Weinberg for EDX 
analyses and Genka Tzolova-Müller for recording the optical spectra. Sophia Klokishner, Oleg Reu, Igor Kasatkin, Annette Trunschke and Robert Glaum are acknowledged for fruitful discussion of the spectroscopic results. Financial support was given by the BMBF (Förderkennzeichen 01RI0529). Robert Schlögl is greatly acknowledged for his continuous support. 


\section{Figure Captions}

Figure 1: Sections of the experimental and calculated powder XRD patterns of a natural sample of malachite (a) (dots: experimental data, blue line: calculated pattern, green line: background, bottom curve: difference plot, ticks: peak positions). Sections of the experimental pattern and refined peak positions (red ticks: malachite, black ticks: rosasite) of the rosasite sample (b). The (20 -1) and (21 -1) reflections of malachite are marked.

Figure 2: Cartoon of precursor nano-structuring upon thermal treatment (calcination and reduction) during $\mathrm{Cu} / \mathrm{ZnO}$ catalyst synthesis: Needle-like $\left(\mathrm{Cu}_{1-\mathrm{x}} \mathrm{Zn}_{\mathrm{x}}\right)_{2}(\mathrm{OH})_{2} \mathrm{CO}_{3}$ crystals decompose and de-mix into $\mathrm{Cu}$ - and $\mathrm{ZnO}$ resulting in a nano-particulate $\mathrm{Cu} / \mathrm{ZnO}$ composite [6], which is shown as HRTEM image for a catalyst with a $\mathrm{Cu}: \mathrm{Zn}$ ratio of $70: 30\left[{ }^{25}\right]$. Nano-structuring is more efficient at $\mathrm{x}$ near 0.5 .

Figure 3: Comparison of the crystal structures of malachite (left) and rosasite (right). A view along the [001] direction (top row) emphasizes their close relationship, while a slight change of the viewing angle onto the (001) plane reveals the different placement of the monoclinic angles (bottom row).

Figure 4: Unit cell of malachite, slightly tilted view towards (50 -1). Only the Jahn-Teller elongated bonds of the $\mathrm{CuO}_{6}$ units are shown. They are oriented either perpendicular to $(20-1)$ (shown in blue) or to (21 -1) (shown in green). The directions of strongest unit cell contraction upon $\mathrm{Cu}-\mathrm{Zn}$ substitution are indicated by arrows. Carbonate groups were omitted for clarity.

Figure 4: Sections of the experimental and calculated XRD patterns of synthetic zincian malachite with nominal Cu:Zn ratios of 100:0 (a), 90:10 (b), 80:20 (c) and 70:30 (d); the different extent of peak shifts is indicated by vertical lines for selected reflections (dots: experimental data, black line: calculated patterns, grey line: background, bottom curve: 
difference plot, ticks: peak positions; the two most intensive aurichalcite reflections are marked in (d) and the aurichalcite peak positions are shown in green)

Figure 5: Trends of lattice parameters $a(\mathrm{a}), b(\mathrm{~b}), c(\mathrm{c}), \beta(\mathrm{d})$ and the distortion parameter $\Delta$ (e) of synthetic zincian malachite as a function of $\mathrm{Zn}$ content. The data represented as circles was taken from [11]. Open symbols in (d) refer to reference data for mineral samples from Table 1 (squares: this study, triangles: literature data of Tab. 1).

Figure 6: Changes in the powder XRD pattern of zincian malachite samples as a function of $\mathrm{Zn}$ content $\mathrm{x}$ for the six most intensive reflections

Figure 7: Correlation between the orientation of the Jahn-Teller elongated $\mathrm{Cu}-\mathrm{O}$ bonds (emphasized in black) and the direction of the monoclinic distortion of the unit cell for malachite (left) and rosasite (right), viewed along the long (top row), middle (center row) and short (bottom row) unit cell axes.

Figure 8: Optical absorption spectra in the UV-vis-NIR range of the minerals malachite (a) and rosasite (e) and of the synthetic zincian malachite samples with $100 \%$ (b), 90\% (c), and $70 \% \mathrm{Cu}(\mathrm{d})$. The grey bars mark the position of the low-energy band determined from a simple fit the range 500-2100 nm with two Gaussians.

Figure 9: Position of the low energy band on the wavelength-scale in the optical absorption spectra of $\left(\mathrm{Cu}_{1-\mathrm{x}} \mathrm{Zn}_{\mathrm{x}}\right)_{2}(\mathrm{OH})_{2} \mathrm{CO}_{3}$ samples as a function of $\mathrm{Zn}$ content. The contribution of the minor amount of by-phases in the two Zn-richest samples (see text) has been neglected.

Figure 10: Proposed energetic situation of the basic carbonate systems $\left(\mathrm{Cu}_{1-\mathrm{x}} \mathrm{Zn}_{\mathrm{x}}\right)(\mathrm{OH})_{2} \mathrm{CO}_{3}$ and $\left(\mathrm{Cu}_{1-\mathrm{x}} \mathrm{Zn}_{\mathrm{x}}\right)_{5}(\mathrm{OH})_{6}\left(\mathrm{CO}_{3}\right)_{2}$, which are important in the context of $\mathrm{Cu} / \mathrm{ZnO}$ catalyst synthesis. This representation is strongly idealized and neglects, e.g., differences in anion composition. 


\section{Tables}

Table 1: Comparison of structural data of natural malachite and rosasite samples reported in literature and in this study. Our rosasite sample contains rosasite as main phase, but also a minor malachite-like fraction (see text). The two longest bonds in each set are emphasized in bold.

\begin{tabular}{|c|c|c|c|c|c|}
\hline & \multirow[t]{2}{*}{ Malachite } & \multirow[t]{2}{*}{ Rosasite } & \multirow{2}{*}{$\begin{array}{l}\text { Malachite } \\
\text { sample }\end{array}$} & \multicolumn{2}{|c|}{ Rosasite sample } \\
\hline & & & & Rosasite & Malachite \\
\hline Reference & {$[1]$} & {$[4,5]^{a)}$} & this study & \multicolumn{2}{|c|}{ this study } \\
\hline a / § & 9.502 & $12.2413(2)$ & $9.4988(4)$ & $12.2266(15)$ & $9.443(3)$ \\
\hline $\mathrm{b} / \AA$ & 11.974 & $9.3705(2)$ & $11.9663(5)$ & $9.3617(10)$ & $12.080(4)$ \\
\hline$c / \AA$ & 3.240 & $3.1612(2)$ & $3.24553(11)$ & $3.1595(3)$ & $3.2037(7)$ \\
\hline$\beta /{ }^{\circ}$ & 98.75 & $98.730(3)$ & $98.636(2)$ & $98.697(8)$ & $97.358(13)$ \\
\hline$V / \AA^{3}$ & 364.35 & 357.90 & $364.72(3)$ & $357.48(6)$ & $362.46(19)$ \\
\hline M1-O4 / A & $1.898(1)$ & $1.952(9)$ & $1.910(10)$ & n.d. & n.d. \\
\hline M1-O5 / ̊ & $1.911(1)$ & $1.89(1)$ & $1.950(9)$ & n.d. & n.d. \\
\hline M1-O1 / ̊ & $1.996(1)$ & $2.078(8)$ & $1.966(11)$ & n.d. & n.d. \\
\hline $\mathrm{M} 1-\mathrm{O} 2 / \AA$ & $2.055(1)$ & $2.057(5)$ & $2.154(13)$ & n.d. & n.d. \\
\hline M1-O1 / A & $2.509(1)$ & $2.443(7)$ & $2.610(13)$ & n.d. & n.d. \\
\hline $\mathrm{M} 1-\mathrm{O} 2 / \AA$ & $2.642(1)$ & $2.519(3)$ & $2.649(15)$ & n.d. & n.d. \\
\hline$\Delta_{\mathrm{M} 1}$ & 0.0185 & 0.0123 & 0.0196 & n.d. & n.d. \\
\hline M2-O4 / ̊ & $1.918(1)$ & $2.01(1)$ & $1.970(12)$ & n.d. & n.d. \\
\hline M2-O5 / A & $1.915(1)$ & $2.07(1)$ & $1.955(11)$ & n.d. & n.d. \\
\hline $\mathrm{M} 2-\mathrm{O} 3 / \AA$ & $2.049(1)$ & $2.046(3)$ & $1.952(11)$ & n.d. & n.d. \\
\hline $\mathrm{M} 2-\mathrm{O} 2 / \AA$ & $2.115(1)$ & $2.256(3)$ & $2.150(11)$ & n.d. & n.d. \\
\hline M2-O5 / § & $2.369(1)$ & $2.251(1)$ & $2.473(13)$ & n.d. & n.d. \\
\hline M2-O4 / § & $2.372(1)$ & $2.16(1)$ & $2.428(14)$ & n.d. & n.d. \\
\hline$\Delta_{\mathrm{M} 2}$ & 0.0079 & 0.0044 & 0.0105 & n.d. & n.d. \\
\hline
\end{tabular}

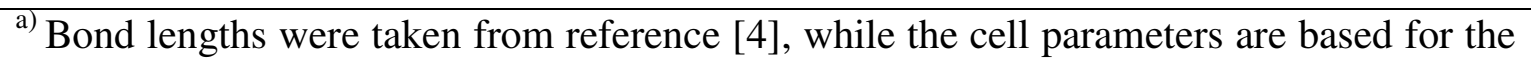
transformed unit cell given in [5]; $n . d .=$ not determined
} 
Table 2: Selected results from the Rietveld refinement of the synthetic zincian malachite samples. The two longest bonds in each set are emphasized in bold.

\begin{tabular}{|c|c|c|c|c|}
\hline Zn content $x$ & 0 & 0.1 & 0.2 & $\approx 0.27$ \\
\hline$a / \AA$ & $9.4938(9)$ & $9.44900(3)$ & $9.4030(7)$ & $9.37228(19)$ \\
\hline$b / \AA$ & $11.9086(11)$ & $11.9749(14)$ & $12.0290(9)$ & $12.060(3)$ \\
\hline$c / \AA$ & $3.2457(3)$ & $3.2198(3)$ & $3.1983(2)$ & $3.1801(5)$ \\
\hline$\beta /^{\circ}$ & $98.684(5)$ & $97.839(6)$ & $96.889(4)$ & $96.190(12)$ \\
\hline$V / \AA^{3}$ & $362.75(5)$ & $360.92(5)$ & $359.15(4)$ & $357.36(12)$ \\
\hline M1-O4 / § & $1.914(15)$ & $1.898(15)$ & $1.926(11)$ & n.d. \\
\hline M1-O1 / Å & $2.020(16)$ & $1.985(4)$ & $2.017(13)$ & n.d. \\
\hline M1-O5 / Å & $2.025(12)$ & $2.057(4)$ & $1.968(11)$ & n.d. \\
\hline M1-O2 / Å & $2.097(18)$ & $2.125(5)$ & $2.066(11)$ & n.d. \\
\hline M1-O1 / ̊ & $2.559(18)$ & $2.428(4)$ & $2.404(14)$ & n.d. \\
\hline M1-O2 / ̊ & $2.66(2)$ & $2.786(6)$ & $2.689(14)$ & n.d. \\
\hline$\Delta_{\mathrm{M} 1}$ & 0.0170 & 0.0190 & 0.0161 & n.d. \\
\hline M2-O4 / A & $1.784(18)$ & $1.855(5)$ & $1.841(14)$ & n.d. \\
\hline M2-O5 / Å & $1.911(18)$ & $1.954(19)$ & $1.993(13)$ & n.d. \\
\hline M2-O3 / ̊ & $2.078(15)$ & $1.974(9)$ & $2.011(12)$ & n.d. \\
\hline M2-O2 / § & $2.082(15)$ & $2.143(3)$ & $2.087(10)$ & n.d. \\
\hline M2-O5 / A & $2.42(2)$ & $2.47(2)$ & $2.347(14)$ & n.d. \\
\hline M2-O4 / § & $2.51(2)$ & $2.406(5)$ & $2.355(16)$ & n.d. \\
\hline$\Delta_{\mathrm{M} 2}$ & 0.0148 & 0.0118 & 0.0080 & n.d. \\
\hline
\end{tabular}


Table 3: Technical details of the Rietveld refinements

\begin{tabular}{llllll}
\hline & $\mathrm{x}=0$ & $\mathrm{x}=0.1$ & $\mathrm{x}=0.2$ & $\mathrm{x} \approx 0.27$ & $\begin{array}{c}\text { malachite } \\
\text { (mineral) }\end{array}$ \\
\hline$R_{\text {exp }}{ }^{\mathrm{a}}$ & 0.0158 & 0.0164 & 0.0150 & 0.0152 & 0.0753 \\
$R_{w p}{ }^{\mathrm{a}}{ }^{2}$ & 0.0406 & 0.0265 & 0.0256 & 0.0264 & 0.0920 \\
$R_{p}{ }^{\mathrm{a}}$ & 0.0308 & 0.0209 & 0.0204 & 0.0207 & 0.0689 \\
$R_{\text {exp }}{ }^{\mathrm{a}}$ & 0.0361 & 0.0574 & 0.0352 & 0.0399 & 0.1701 \\
$R_{w p}{ }^{\mathrm{a}}$ & 0.0928 & 0.0932 & 0.0602 & 0.0696 & 0.2079 \\
$R_{p}{ }^{\mathrm{a}}$ & 0.0813 & 0.0867 & 0.0547 & 0.0609 & 0.2152 \\
$\mathrm{GOF}$ & 2.57 & 1.62 & 1.71 & 1.74 & 1.22 \\
$R_{\text {Bragg }}$ & 0.01060 & 0.00846 & 0.00452 & 0.00561 & 0.02989 \\
No. of reflections & 225 & 224 & 222 & 221 & 226 \\
No. of parameters & 57 & 57 & 57 & 39 & 51 \\
\hline
\end{tabular}

${ }^{\text {a }}$ Primed $R$ values are background corrected; definition of the $\mathrm{R}$ values according to [26]. 


\section{References}

[1] F. Zigan, W. Josig, H. D. Schuster, Z. Kristallogr. 1977, 145, 412.

[2] M. Behrens, F. Girgsdies, A. Trunschke, R.Schlögl, Eur. J. Inorg. Chem. 2009, $10,1347$.

[3] A. C. Roberts, J. L. Jambor, J. D. Grice, Powd. Diff. 1986, 1, 56.

[4] N. Perchiazzi, Z. Kristallogr. Suppl. 2006, 23, 505.

[5] N. Perchiazzi, S. Merlino, Eur. J. Mineral. 2006, 18, 787.

[6] M. Behrens, J. Catal. 2009, 267, 24.

[7] D. Waller, D. Stirling, F. S. Stone, M. S. Spencer, Faraday Discuss. Chem. Soc. 1989, 87, 107.

[8] T. Fujitani, J. Nakamura, Catal. Lett. 1998, 56, 119.

[9] R. G. Herman, K. Klier, G. W. Simmons, B. P. Finn, J. B. Bulko, T. P. Kobylinski, J. Catal. 1979, 56, 437.

[10] P. Porta, G. Fierro, M. Lo Jancono, G. Moretti, Catal. Today 1988, 2, 675.

[11] P. Porta, S. De Rossi, G. Ferraris, M. Lo Jacono, G. Minelli, G. Moretti, J. Catal. 1988, $109,367$.

[12] S. Schimpf, M. Muhler in Synthesis of Solid Catalysts ed. K. P. de Jong, WileyVCH., Weinheim, 2009, $329 \mathrm{ff}$.

[13] R. K. Eby, F. C. Hawthorne, Acta Cryst. 1993, B49, 28.

[14] I. V. Pekov, N. Perchiazzi, S. Merlino, V. N. Kalachev, M. Merlini, A. E. Zadov, Eur. J. Mineral. 2007, 19, 891.

[15] B. J. Hathaway, D. E. Billing, Coord. Chem.Rev. 1970, 5, 143.

[16] K. M. Reddy, A. S. Jacobs, B. J. Reddy, Y. P. Reddy, Phys. Status Solidi 1987, B139, K145.

[17] R. Glaum, M. Weil, D. Özalp, Z. Anorg. Allg. Chem. 1996, 622, 1839

[18] R. L. Frost, B. J. Reddy, D. L. Wain, W. N. Martens, Spectrochim. Acta 2007, A66, 1075.

[19] M. M. Harding, B. M. Kaiuki, R. Cernik, G. Cressey, Acta Cryst B. 1994, 50, 673.

[20] J. M. Charnock , P. F. Schofield, C. M. B. Henderson, G. Cressey, B. A. Cressey, Mineral. Mag., 1996, 60, 887. 
[21] B. Bems, M. Schur, A. Dassenoy, H. Junkes, D. Herein, R. Schlögl, Chem. Eur. J. 2003, 9, 2039.

[22] A. K. Alwan, J. H. Thomas, P. A. Wiliams, Transition Met. Chem. 1980, 5, 3.

[23] A. M. Pollard, M. S. Spencer, R. G. Thomas, P. A. Williams, J. Holt, J. R. Jennings, Appl. Catal. A 1992, 85, 1.

[24] A. A. Coelho, Topas, General Profile and Structure Analysis Software for Powder Diffraction Data, Version 3.0, Bruker AXS GmbH, Karlsruhe, Germany, 2006.

[25] I. Kasatkin, P. Kurr, B. Kniep, A Trunschke, R. Schlögl, Angew. Chem. 2007, 119,7465 .

[26] R. A. Young in The Rietveld Method, ed. R.A. Young, Oxford University Press 1993, $1 \mathrm{ff}$. 


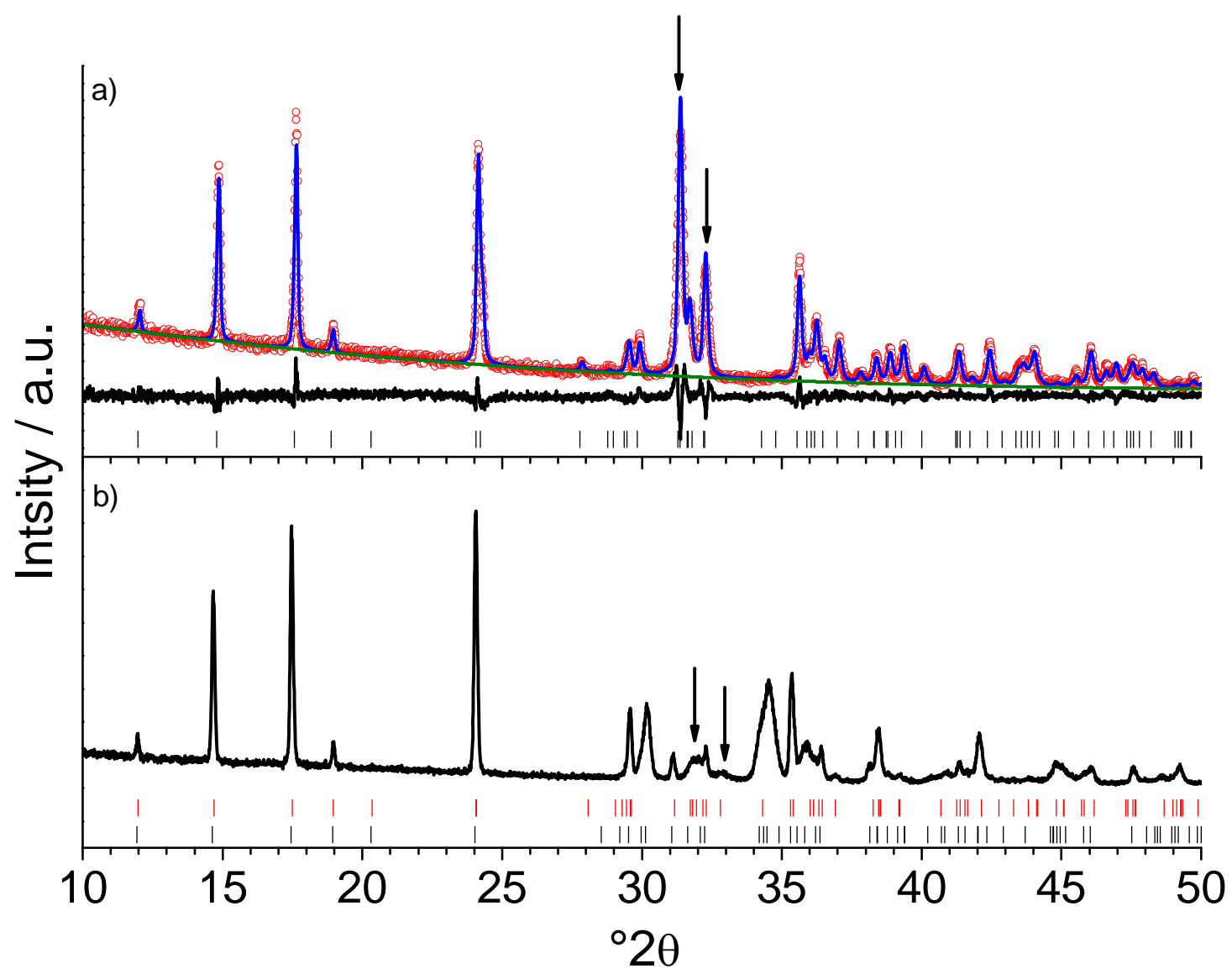

Figure 1 


\section{Page 23 of 32}
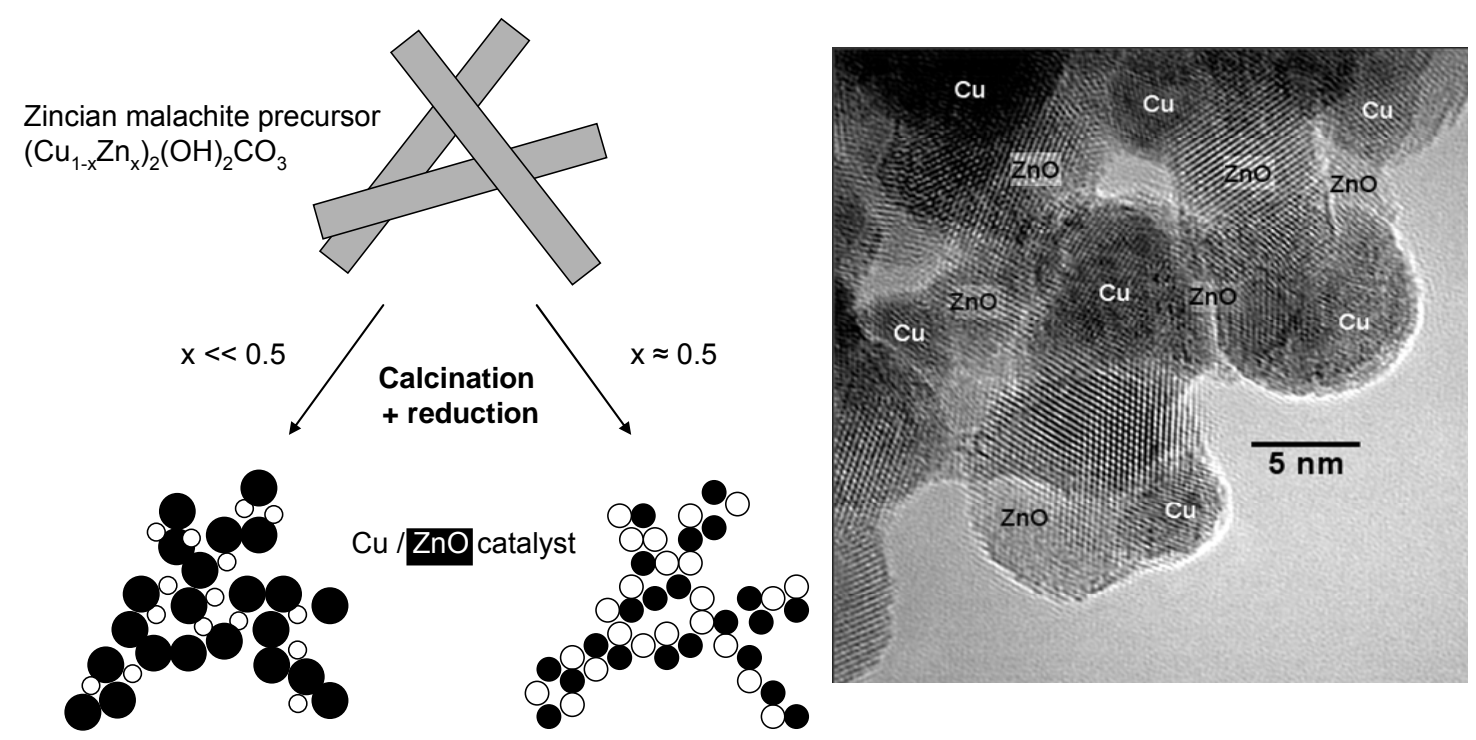

Figure 2 

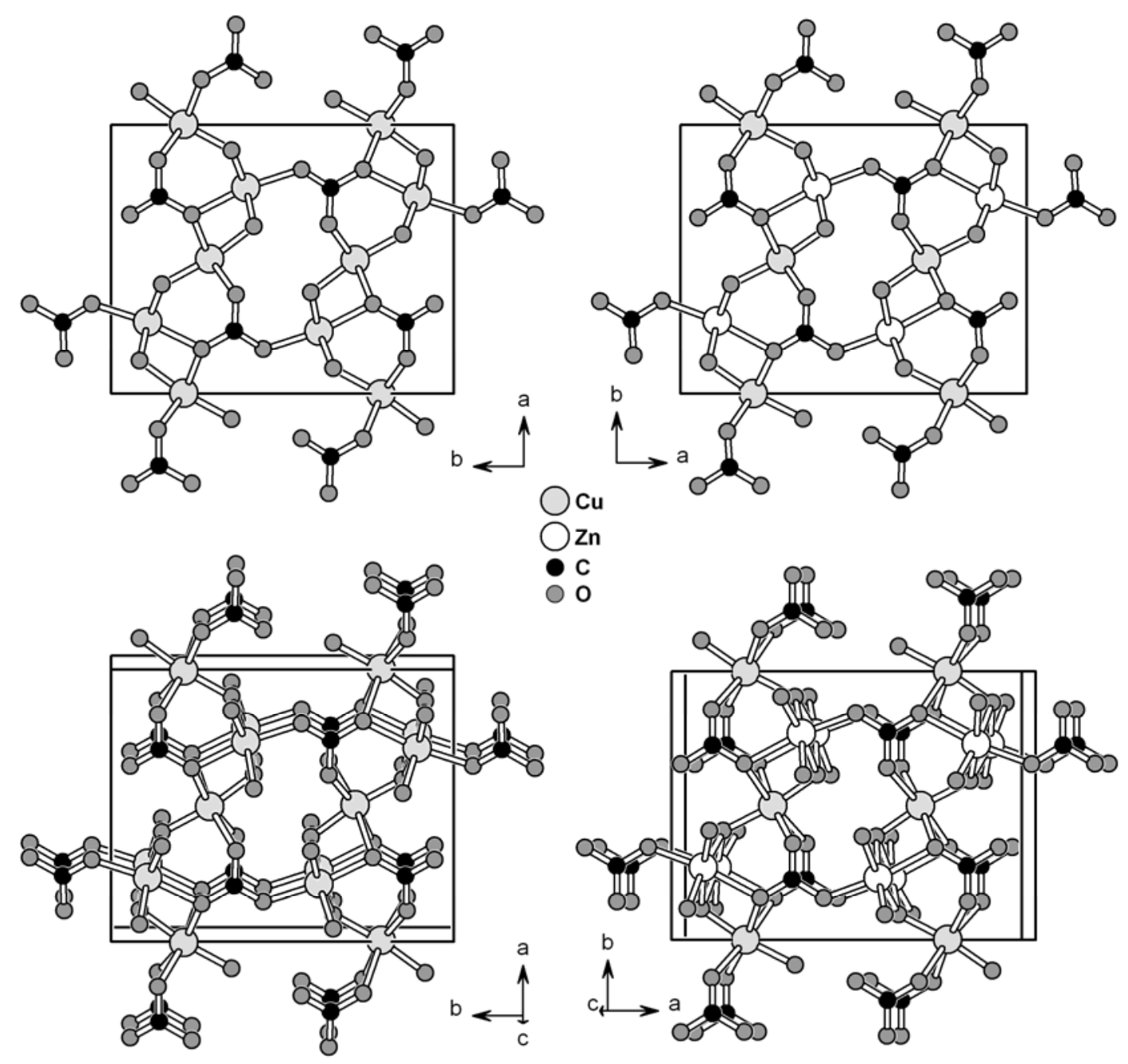

Figure 3 


\section{Page 25 of 32}

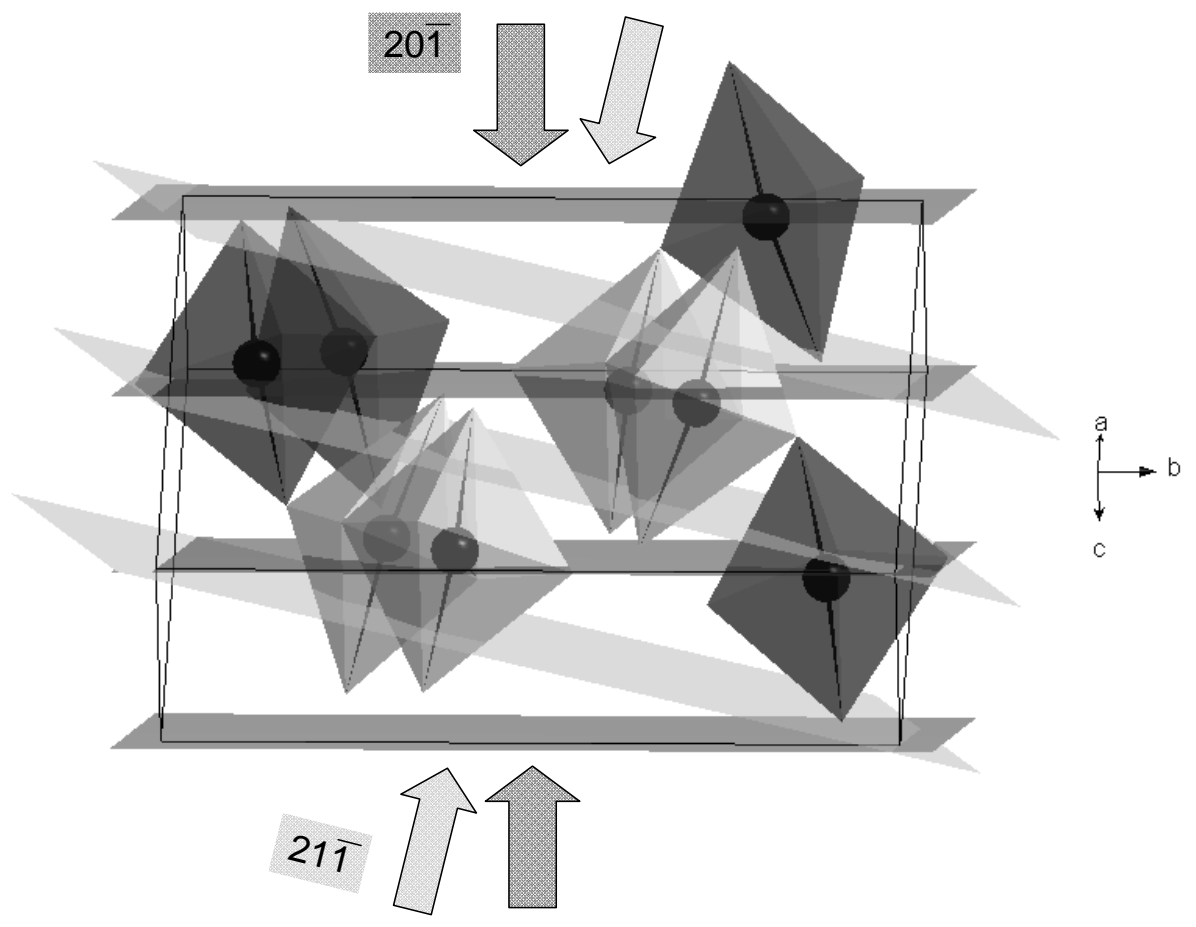

Figure 4

29

31

33

34

35

36

37

38

39

40

41

42
43

44

45

46

47

48

49

51

52

53

54

55

56 

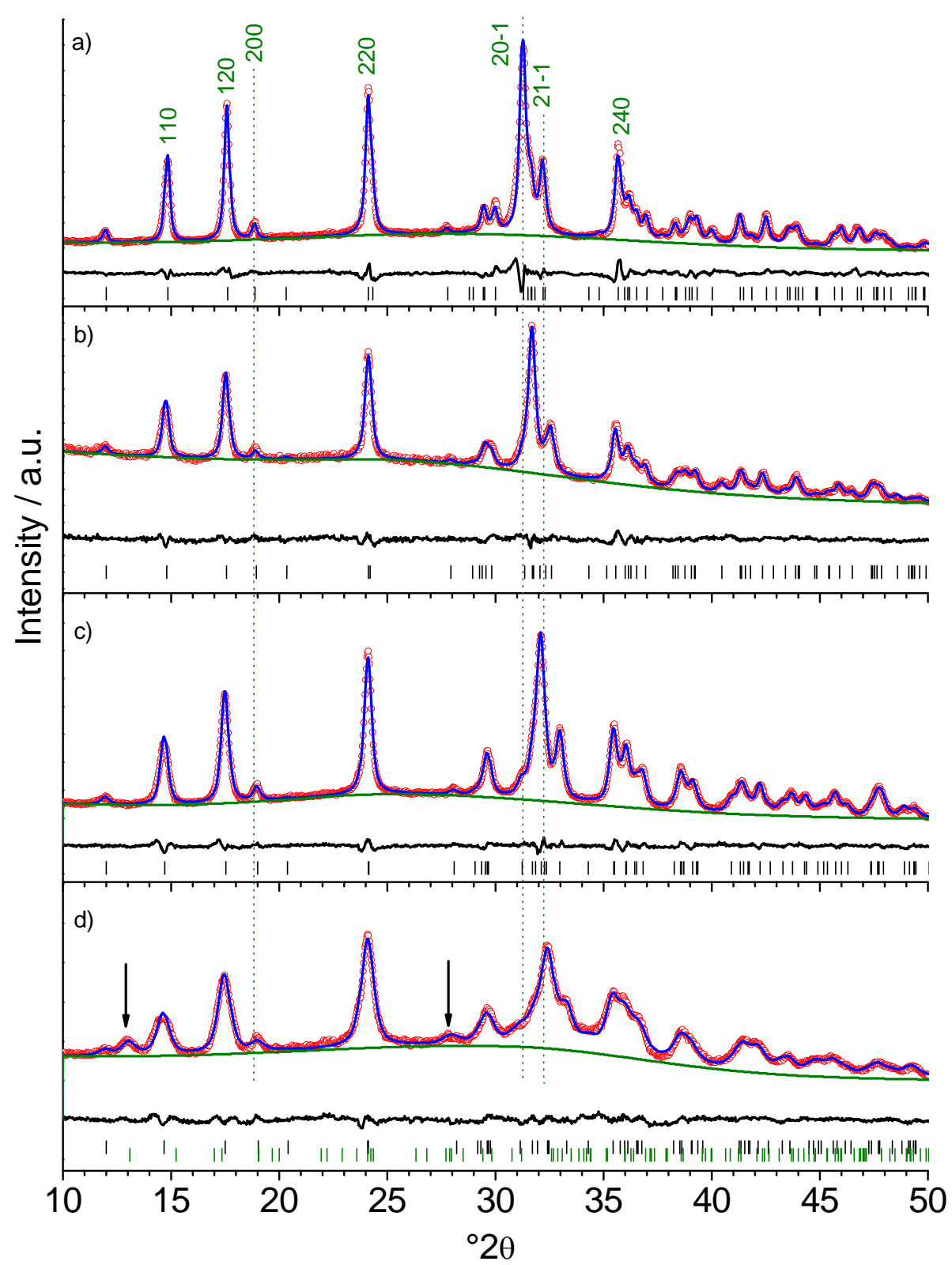

Figure 5 

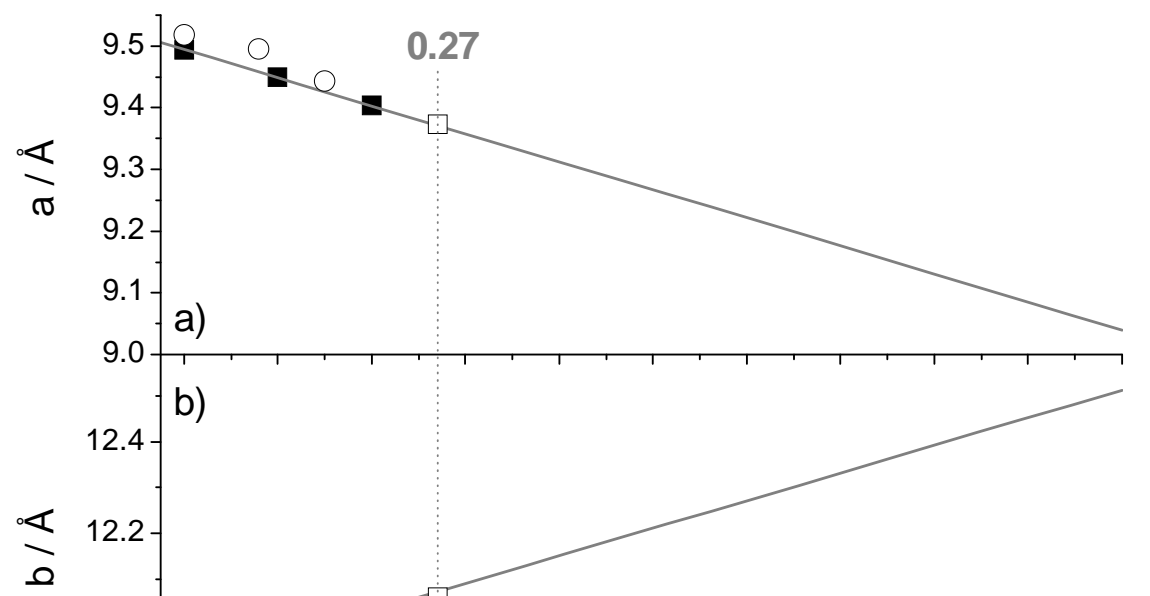


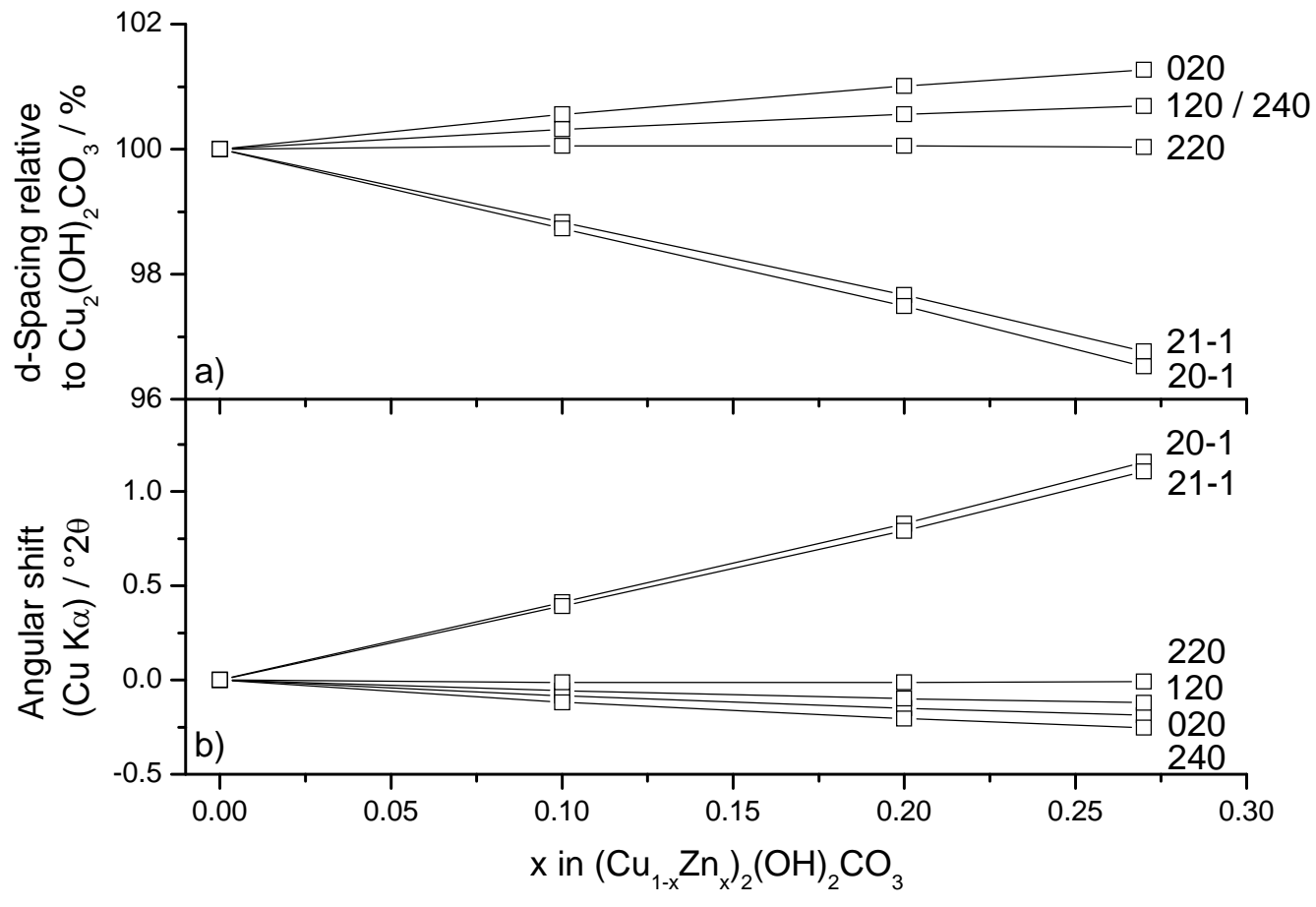

Figure 7 

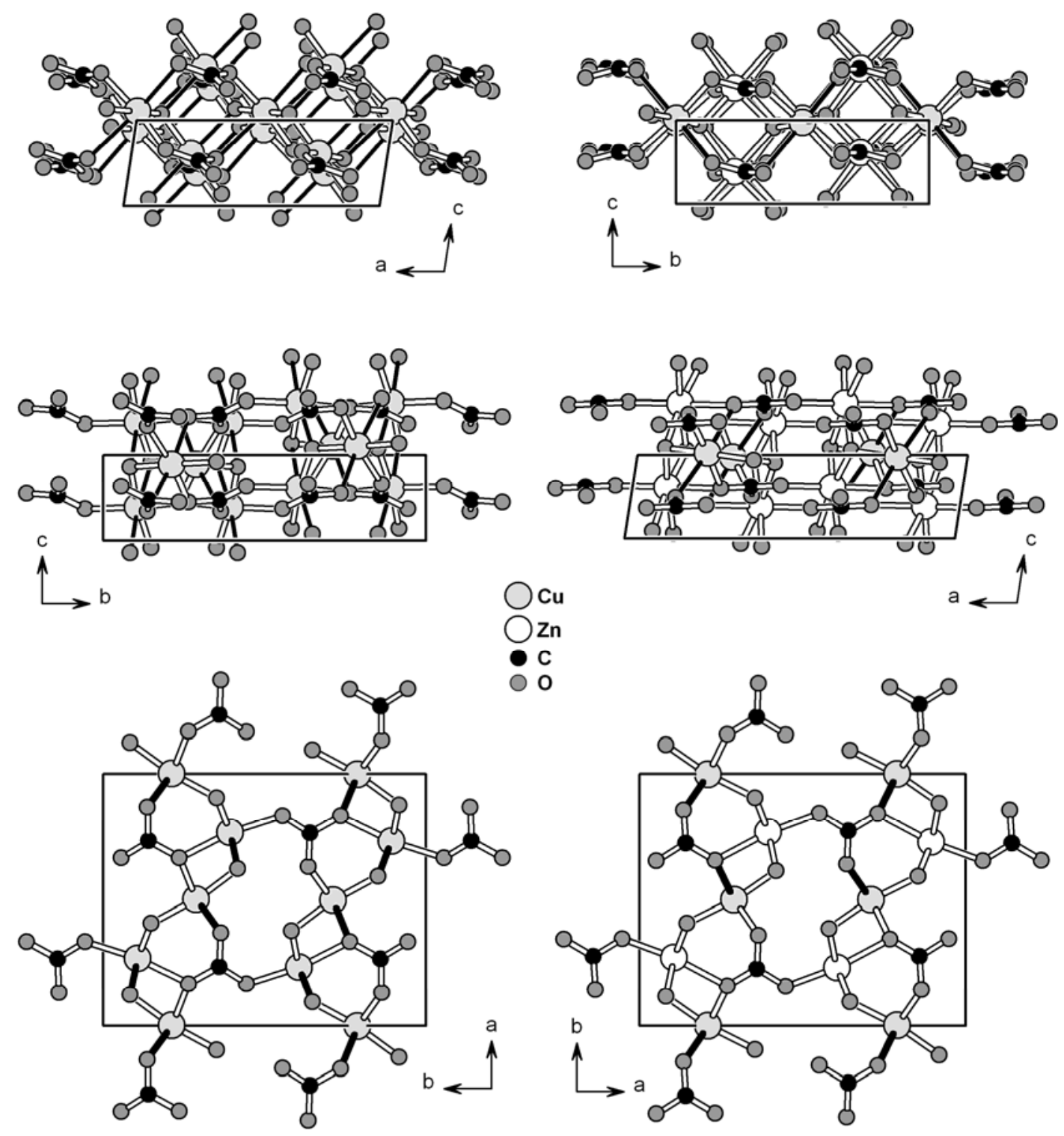

Figure 8 


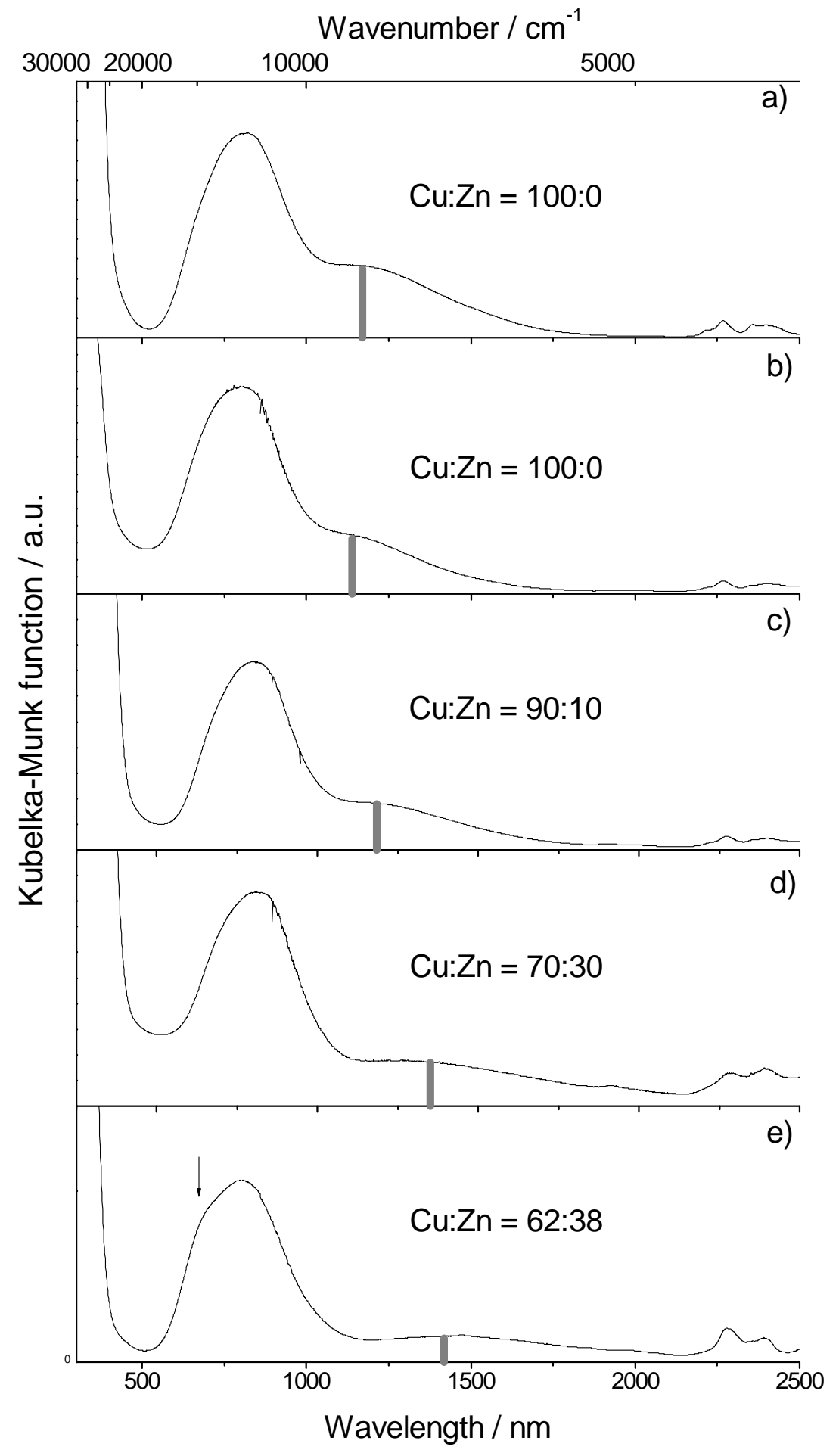

Figure 9 


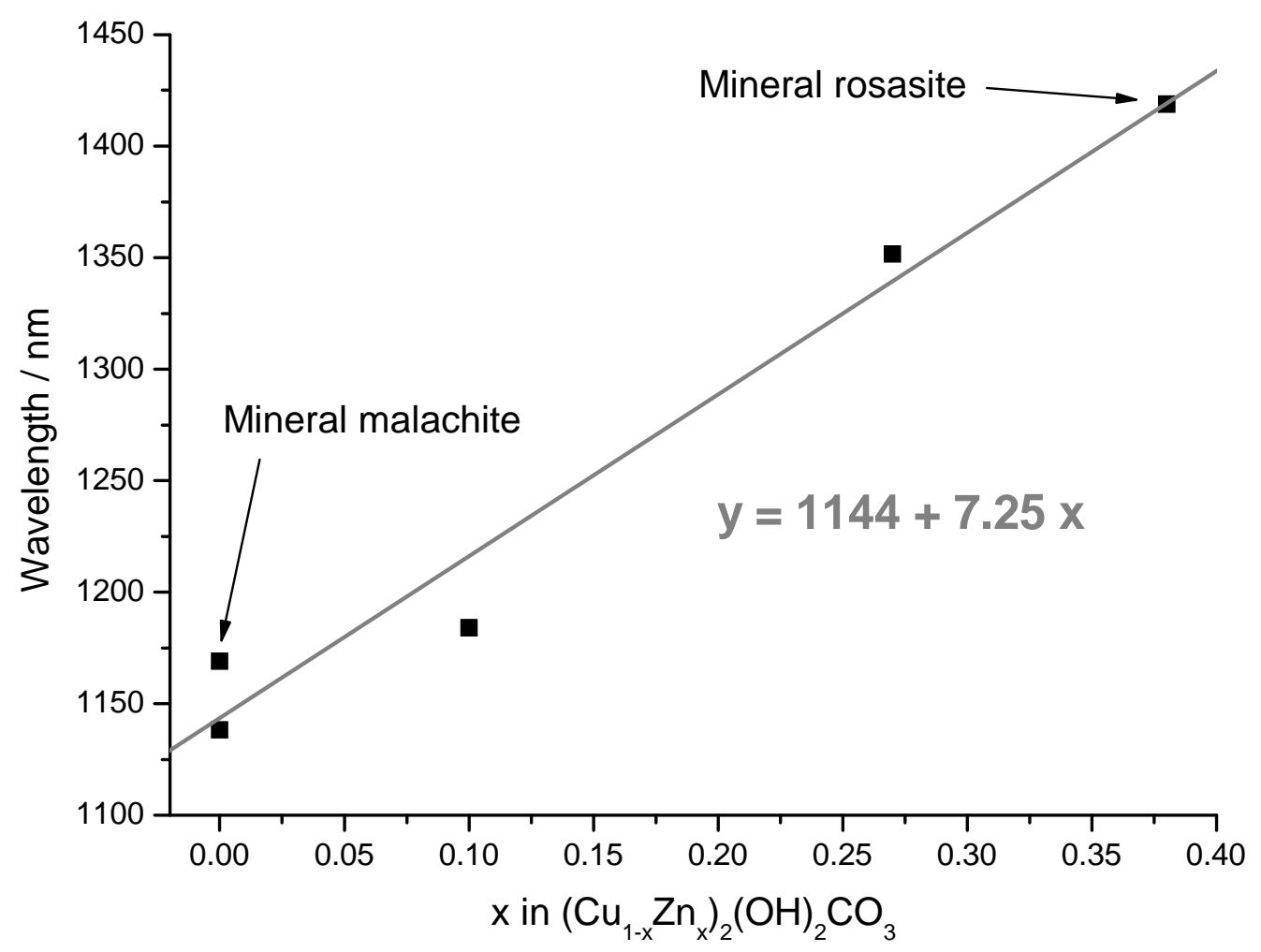

Figure 10 


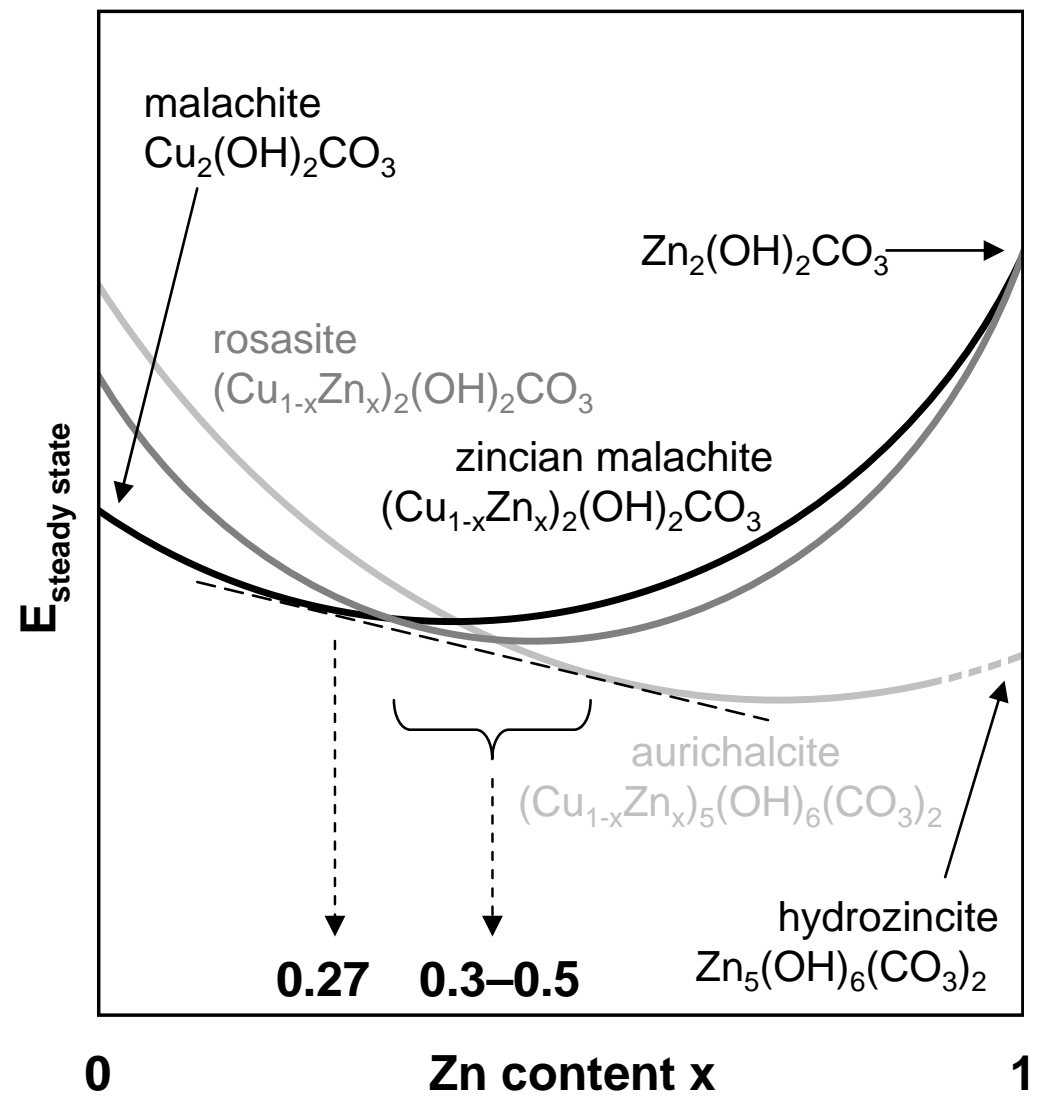

Wiley-VCH 